\title{
Teachers' Reflective Thinking Practice: Descriptive Study during COVID-19 in SMP N 2 Singaraja, Bali
}

\author{
Ni Putu Harista Wati ${ }^{1}$ \\ Universitas Pendidikan Ganesha, Indonesia \\ niputuharistawati03@undiksha.ac.id \\ I Putu Ngurah Wage Myartawan ${ }^{2}$ \\ Universitas Pendidikan Ganesha, Indonesia \\ wmyartawab@undiksha.ac.id \\ Luh Gede Eka Wahyuni ${ }^{3}$ \\ Universitas Pendidikan Ganesha, Indonesia \\ ekawahyuni@undiksha.ac.id
}

\begin{abstract}
The study aims to analyze the English teachers' perceptions about reflective thinking in SMP N 2 Singaraja. This research conducted using a descriptive qualitative method. The participants were four English teachers in SMP N 2 Singaraja. The data collection was done through Google form questionnaire that consists of 20 statements in which have five options in each statement such as Always (5), Often (4), Sometimes (3), Rarely (2), and Never (1). Moreover, the teachers should fill in based on their experiences. The results showed that four teachers were in advanced level of reflective thinking teachers. The results of this study are expected to be a baseline for future improvement of reflective thinking during the online learning. Further study is needed because it is only describing on how teachers perceived themselves as reflective thinking in online learning, although this study needs further study in actual action of reflective thinking.
\end{abstract}

Keywords: Reflective Thinking Practice, Online Learning.

\section{INTRODUCTION}

The online learning is the solutions that needs for teachers still capable of teaching their students in this COVID-19 situation. Meanwhile, the teachers need to reach students' goal, they have important roles as good English teachers in doing online learning. The role of the teachers is to ensure their achievement of minimal competence in implementing teaching and learning process. There are four competencies of the teachers by Regulation of Republic of Indonesia Number 14 in 2004 which include pedagogic competence, personality competence, professional competence, and social competence. It also states that these competencies have a relationship with the skill, attitudes, and behavior obtained based on experience. Moreover, to get the achievement in implementing four competencies, teaching and learning process must be effective and efficient. Therefore, the teachers must look back what happened in 
their past experience in teaching. Thus, the teachers have to do self-reflection in their practice (Ratminingsih et al., 2017).

The reflection itself is a common thing for the teachers. According to National Commission on Teaching and America' Future (1996) as cited in Rodgers (2002), a reflection is teachers' obligation to think their practice and experience, so they can do reflection by seeing their practice, asking advice from colleagues, reading a research educational journal, thinking critically, and do self-assessment on what the strengths and weaknesses in teaching practice. Therefore, teachers must do reflection in any situation that will help them to guide students on how the students understand material. Reflective thinking is a step in how teachers think about their teaching and learning process by looking back at it (Phelps, 2005). Thus, reflection can motivate their thought to be critical thinking by going back to their practice.

Based on the preliminary interview, the researcher found that the English teachers in SMP N 2 Singaraja were doing reflection in order to know whether they are succeeding or not on their teaching and learning process. They were asked to do reflection on their learning activities and make reports to find out how far schools' program running well during pandemic situation. For example, the teachers instructed the students to make a learning journal that they should fill after lesson. Thus, since the students encountered many problems in the classroom, the teachers needed to make reflective journal by the students' perspective. Moreover, it can be done after each activity or lesson, thus the students have to write down in the notebook about what happened in the classroom (Mathew et al., 2017.). In the journal, the students can write down their reaction and emotion which happened in that teaching and learning process based on their perspective. Thus, in this situation which the teachers used their critical thinking to do self-reflection is depicting that the teachers already do reflective thinking. Schon (1987) states that reflective thinking is about teachers' self-assessment in their teaching practice. According to Burbank et al. (2012), reflection is about how teachers analyze and deal with the problems and make improvement in the next teaching process. Therefore, the teachers would be determined as good reflective thinking teachers by four skills.

There are four skill that imposed teachers as reflective thinking teacher. The first is lifelong learning skills, it can be seen as reflective thinking of as teachers do assessments continuously, evaluate their teaching practice, and it is influenced the students' needs (Choy \& Yim, 2017). The teachers can be said as advanced teacher, if they know what they have to do as the teacher and improve the feedback from supervisor and students from the better teaching and learning process. The second is self-assessment, according to (Chee Choy et al., 2012), reflection can be thought of as self-assessment as stepping back from what they have been taught before and improve it in the current teaching process. It can be seen as an advanced teacher in self-assessment in which the teachers always think about their performance and improve it for the next lesson. Next is selfbelief, it can be said as a reflection, if the teachers have highly metacognitive awareness of themselves and find out the strategies that work with the problems to reach their goals in the teaching practice (Balta, 2018). It can be seen as an advanced teacher in which the teachers worried about their belief will be affected their behavior towards in relation to their students. The last is teaching awareness, awareness of the teachers can be said as a reflection of as the 
teachers need to analyze and understand their problems in the teaching process (Chee Choy et al., 2012). It can be seen as an advanced teacher in which the teachers have to consider their past performance and connect it with the next performance to help them to be a better teacher. Therefore, if the teachers can implement those four skills as advanced teacher, it can be said that they are reflective teachers. Based on that explanation, this study was raised.

Riyanti (2020) conducted a case study about students' (EFL pre-service teachers) reflections in teaching practicum. They argued that reflective practice is a tool for improving teachers' professional. The study was categorized as qualitative case study with six pre-service teachers who take microteaching. The study used several methods to collect the data which are open-ended questionnaire, journal writing, participants' analysis on their videos performance in teaching, and interview. The finding of this study showed that the participants perceived that reflection is a good for them to look back at their teaching practicum. It is also stated that the participants did reflection in different stage of teaching and level.

On the other hand, Choy \& Yim (2017) conducted a study about reflective thinking of the teachers. They argued that teachers should aware of reflection in their teaching and learning process because it helps them to know their strengths and weaknesses. They studied the perception of Malaysian teachers in reflective thinking. The participant was 1070 preservice teachers. The data were collected by self-report questionnaire. This research used structural equation modeling (SEM) by analyzing five construction such as lifelong skill, self - assessment, self-belief, teaching awareness, and also reflective thinking itself. The result of this study is reflective thinking guides to self-assessment, teaching awareness, and self-belief, all of these are traits of the teachers who competent.

Different from previous research, Töman (2017) is conducted a study of teachers' reflective thinking stages. It is stated that reflective thinking is important for the teachers to know their strengths and weaknesses in the teaching and learning process and they can improve their teaching skills. This study is taken place in Bayburt University Faculty of Education Department of Elementary Science Education by investigating four pre-service teachers. To collect the data, the researcher is used video and reflective diaries. This study is used qualitative study in using the content analysis method. The finding of this study differentiates between three stages such as planning, processing, and evaluating.

Due to those explanations, it was recognized that reflective thinking is important for teachers by connecting four skills. Therefore, the aimed of this study was to analyze the English teachers' perceptions on reflective thinking in SMP N 2 Singaraja. There is no study conducted yet for secondary English school teachers in SMP N 2 Singaraja. The novelty is no researcher is found to discuss the matter in online learning. For that reason, it is considered to investigate on how the English teachers perceived themselves as reflective thinking teachers during the online learning.

\section{METHOD}




\section{Research Method}

The research design of this study was a descriptive quantitative study. This method was used for English teachers' perceptions towards reflective thinking practice and knows the problems that teachers face in doing reflective thinking practice in online learning. The data analysis and findings are described descriptively in the form of number. Moreover, the descriptive research was asked about the notion and the effect of variables. According to Ary et al., (2010), to collect the data such as interview, document review, and observation in phenomenon that might be understood by descriptively. This research were used Teachers' Reflective Thinking Questionnaire (TRTQ) to describe teachers' perceptions on reflective thinking practice, meanwhile the interview was used for describing the problems in reflective thinking practing in online learning. Thus, the researcher used those instruments to collect the data in SMP N 2 Singaraja. Respondents

The participants of this research were 4 English teachers in SMP N 2 Singaraja who taught English subject for $7^{\text {th }}$ and $8^{\text {th }}$ grade students. They were selected as subject because the researcher was observed all of them to conduct the reflective thinking in their online teaching and learning process.

\section{Instruments}

The data collection was obtained from self-rated questionnaire by four English teachers in SMP N 2 Singaraja. It can be seen in the table below.

\section{Table 3.1 Technique of Collecting the Data and Research Instrument}

\begin{tabular}{clrll} 
No & $\begin{array}{l}\text { Statements Of The } \\
\text { Problems }\end{array}$ & Instruments & $\begin{array}{l}\text { Source } \\
\text { of Data }\end{array}$ & $\begin{array}{l}\text { Data Collection } \\
\text { Procedure }\end{array}$ \\
\hline 1. & $\begin{array}{l}\text { How do } \\
\text { teachers English The researcher } \\
\text { themselves as reflective } \\
\text { thinking teachers? }\end{array}$ & $\begin{array}{l}\text { Teachers } \\
\text { and self-rated }\end{array}$ & $\begin{array}{l}\text { The researcher gives } \\
\text { self-rated }\end{array}$ \\
& & $\begin{array}{l}\text { questionnaire to know } \\
\text { the level of reflective } \\
\text { thinking of English } \\
\text { teachers. }\end{array}$
\end{tabular}

Based on the table 3.1 , it can be seen that the techniques of collecting the data were self-rated questionnaire and interview guide. Therefore, it was explained briefly as follows.

\section{Teachers' Reflective Thinking Questionnaires}

Teachers' Reflective Thinking Questionnaire was completed by the English teachers. This questionnaire aimed to measure the teachers perceived themselves as reflective thinking teachers. The statements of the questionnaire is based on theory of reflective thinking which divided into 4 skills, namely lifelong learning skill, self-belief, self-assessment, and teaching awareness by Choy \& Yim (2017). The questionnaire was number of scales which was asked to rate on a scale of $1-5$ ( 1 as strongly disagree and 5 as strongly agree). This scale showed how English teachers perceived themselves as reflective thinking 
teacher during the online learning. Reflective thinking can be assessed by several theories that chosen by the researcher. These theories are used to know how English teachers perceive themselves as reflective thinking teacher and the challenges in doing reflective thinking.

Table 3.2 Blueprint of Teachers' Reflective Thinking Questionnaire

Skills

Indicators

Items

The ability of teachers to do the continuous
assessments and evaluation of their teaching and 1,2, 3, and 4
learning proses.

Skill

Teachers are able to engage the students with the appropriate learning strategies and implement 5,6 , and 7 the components of lifelong learning skills.

The teachers can do the self-assessment by considering the feedback given from the student and the experiences from teaching and learning

Self-Assessment they conduct in the classroom.

Ability

Self-assessment can make the teachers to be more reflective on their teaching and indicate that teachers implement the reflective thinking skills toward the students.

The way of how teachers see themselves between their students and their teaching ability.

12 and 13

Self-Belief

The teachers who do the reflection tent to have more self-belief and master the experience more.

14 and 15

The ability of teachers to release their role toward the students.

16 and 17

Teaching

Awareness

Reflective thinking should be foreshadowed by the awareness of experiences happened before.

18,19, and 20

\section{Procedure}

In the data collection, the teachers were asked to fill out a questionnaire based on their experiences that had been uploaded on Google form. All statements related to the level of reflective thinking teachers with the implementing the online learning. After the data were collected, the results were categorized and analyzed following scale statements. From that, the data from each skill were shown whether the teachers have advanced, intermediate, or 
introductory level of reflective thinking by using percentage. The table of category it can be seen as follows.

Table 3.3 Criteria of English Teachers Perceived Knowledge of Reflective Thinking

\begin{tabular}{|c|c|c|c|}
\hline \multicolumn{2}{|r|}{ Interval Value } & $\begin{array}{l}\text { General } \\
\text { Criteria }\end{array}$ & $\begin{array}{l}\text { Criteria of English Teachers } \\
\text { Perceived Knowledge of } \\
\text { Reflective Thinking }\end{array}$ \\
\hline \multicolumn{2}{|r|}{$\boldsymbol{X} \geq \mathrm{Mi}+1.5 \mathrm{Sdi}$} & Excellent & \multirow{2}{*}{$\begin{array}{c}\text { Advanced Reflective Thinking } \\
\text { Teacher }\end{array}$} \\
\hline $\mathrm{Mi}+$ & $0.5 \mathrm{Sdi} \leq \boldsymbol{X} \geq \mathrm{Mi}+1.5 \mathrm{Sdi}$ & Good & \\
\hline \multicolumn{2}{|c|}{$\mathrm{Mi}-0.5 \mathrm{Sdi} \leq X \geq \mathrm{Mi}+0.5 \mathrm{Sdi}$} & Average & $\begin{array}{c}\text { Intermediate Reflective } \\
\text { Thinking Teacher }\end{array}$ \\
\hline \multicolumn{2}{|c|}{$\begin{array}{c}\text { Mi - 1.5Sdi } \leq X \geq \mathrm{Mi}-0.5 \mathrm{Sdi} \\
\boldsymbol{X}<\mathrm{Mi}-1.5 \mathrm{Sdi}\end{array}$} & Poor & Introductory Reflective \\
\hline \multicolumn{4}{|l|}{ Noted: } \\
\hline$x$ & \multicolumn{3}{|c|}{$=$ value get from the teachers } \\
\hline score) & \multicolumn{3}{|c|}{$=$ ideal score that obtained from $1 / 2$ (maximum score + minimum } \\
\hline Sdi & $=$ standard devic & at obtained & $\mathrm{m} 1 / 3(\mathrm{Mi})$ \\
\hline
\end{tabular}

\section{FINDINGS AND DISCUSSIONS}

This part shows the data which include self-questionnaire and interview. As the purpose of this study were to describe and analyze the teachers' perceived knowledge of reflective thinking and the challenges in doing selfreflection in implementation in online learning in SMP N 2 Singaraja. Therefore, to know how English teachers perceived themselves as reflective thinking teachers, the researcher used theory from Choy \& Yim (2017) and collect the data by using self-rated questionnaire. Moreover, to know the challenges in selfreflection that the teachers face during the online learning, the researcher used interview to collect the data. The finding and discussion are elaborated as follows.

Teachers' Perceived Knowledge of Reflective Thinking Implementation in Online Learning

The researcher used theory from Choy \& Yim (2017) as a grounded theory for making questionnaire in which included four skills of reflective thinking, namely life-long learning skills, self-belief, self-assessment, and teaching awareness. In this questionnaire, the teachers answered 20 statements towards reflective thinking. There are five options in which each statement such as Always (5), Often (4), Sometimes (3), Rarely (2), and Never (1). The questionnaire filled by the English teachers in SMP N 2 Singaraja as follows.

Table 4.1 Result of Teachers' Perceived Knowledge of Their Reflective Thinking Practice 
The Art of Teaching English as a Foreign Language, Vol.2 No.2 2021

p-ISSN : 2656-8942, e-ISSN : 2684-8546

DOI: $10.36663 /$ tatefl.v2i2.135

\begin{tabular}{|c|c|c|c|c|c|}
\hline \multirow{2}{*}{ No } & \multirow{2}{*}{ Statement } & \multicolumn{4}{|c|}{ Teachers } \\
\hline & & 1 & 2 & 3 & 4 \\
\hline \multicolumn{6}{|c|}{ Life-Long Learning } \\
\hline 1 & $\begin{array}{l}\text { I need to find the most effective strategies for my } \\
\text { students, considering their characteristics and the } \\
\text { material. }\end{array}$ & 4 & 4 & 5 & 4 \\
\hline 2 & $\begin{array}{l}\text { I get inspiration from my colleagues for an } \\
\text { innovative way of teaching. }\end{array}$ & 3 & 4 & 4 & 3 \\
\hline 3 & $\begin{array}{l}\text { I evaluate my teaching practice to see the } \\
\text { effectiveness. }\end{array}$ & 4 & 2 & 5 & 4 \\
\hline 4 & $\begin{array}{l}\text { I ask for feedback from students and colleagues } \\
\text { to reflect on what I present to my class since I } \\
\text { know it will influence how my students will behave } \\
\text { toward the lesson. }\end{array}$ & 2 & 2 & 4 & 1 \\
\hline 5 & $\begin{array}{l}\text { I never integrate my past experience into my } \\
\text { current teaching practice for better preparation. }\end{array}$ & 5 & 3 & 5 & 3 \\
\hline 6 & $\begin{array}{l}\text { I integrate my past experience into my current } \\
\text { teaching practice for better preparation. }\end{array}$ & 4 & 3 & 5 & 4 \\
\hline 7 & $\begin{array}{l}\text { I think of what I had done during my lessons so I } \\
\text { can improve and discover myself to apply the } \\
\text { knowledge towards the students so I can be a } \\
\text { better teacher in the future }\end{array}$ & 4 & 3 & 5 & 4 \\
\hline
\end{tabular}

\section{Self-Assessment}

\begin{tabular}{lllllll}
\hline 8 & $\begin{array}{l}\text { I get good comments from students so I think I am } \\
\text { doing quite well overall as a teacher. }\end{array}$ & 3 & 3 & 2 & 2 \\
\hline $9 \begin{array}{l}\text { I consider my students' feedback important as it } \\
\text { will help me understand them better and it can be } \\
\text { the indicator of the areas of my strengths and } \\
\text { weaknesses. }\end{array}$ & 3 & 4 & 5 & 4 \\
\hline $10 \begin{array}{l}\text { I make assumptions toward my colleagues' } \\
\text { feedback and I learn from them. }\end{array}$ & 3 & 4 & 4 & 4 \\
\hline 11 & $\begin{array}{l}\text { I put my students' feedback aside. I just need to } \\
\text { teach them, not more. }\end{array}$ & 5 & 4 & 5 & 5 \\
\hline
\end{tabular}

\section{Self-Belief}

I believe I can take care of my needs as a teacher such as providing lesson plan, learning media,

12 and also understanding the material that will be $\begin{array}{lllll}4 & 5 & 5 & 5\end{array}$ taught before transferring the knowledge to students.

13 I try to look for the connecting areas between

13 what and how I teach with my life experiences. $\quad \begin{array}{lllll}4 & 3 & 5 & 4\end{array}$

I know the mistakes that I made during my
14 teaching process can have an impact on my 3
students' lives. 
The Art of Teaching English as a Foreign Language, Vol.2 No.2 2021

p-ISSN : 2656-8942, e-ISSN : 2684-8546

DOI: $10.36663 /$ tatefl.v2i2.135

I feel very anxious about students' feedback given

15 to me, as it is obvious that they assess and judge me as a person.

Teaching Awareness

\begin{tabular}{llllll}
\hline 16 & $\begin{array}{l}\text { In order to improve my teaching, I try to think } \\
\text { about what I teach my students in terms of my } \\
\text { own area of discipline. }\end{array}$ & 4 & 3 & 5 & 4 \\
\hline 17 & $\begin{array}{l}\text { I have a set of practices which I am comfortable } \\
\text { with, although the feedback I receive from } \\
\text { students and my colleagues will help me further } \\
\text { enhance those practices. }\end{array}$ & 3 & 4 & 5 & 4 \\
\hline $\begin{array}{l}\text { My self-quality and the set of my teaching } \\
\text { practices will be influenced by my beliefs. }\end{array}$ & 4 & 5 & 5 & 4 \\
\hline 19 & $\begin{array}{l}\text { I do not know my behavior will ultimately be } \\
\text { controlled by what I believe about myself as a } \\
\text { teacher towards students' lives. }\end{array}$ & 3 & 5 & 2 \\
\hline 20 & $\begin{array}{l}\text { I try to reflect on what I do during my lessons so I } \\
\text { can enrich the strategies I use with new and more } \\
\text { effective ones. }\end{array}$ & 4 & 3 & 5 & 4 \\
\hline Total point & 70 & 68 & 90 & 72 \\
\hline Total Score & $75 \%$ &
\end{tabular}

The table above showed that the Teacher 1 (T1) perceived knowledge of reflective thinking that he was good in reflecting his teaching and learning process during online learning with total score of 72 . Teacher 2 (T2) perceived knowledge of reflective thinking was average with the total score 68. Meanwhile, Teacher 3 (T3) got the biggest score than others which his score of 90 in reflecting his teaching and learning process, it means he was excellent. Therefore, teacher 4 (T4) perceived knowledge of reflecting thinking was good in reflecting his teaching and learning process and she got 72 . Generally, from four teachers, it can be said that they perceived themselves as good in reflecting their teaching and learning process with the average score of 75 . It showed that the English teachers in SMP N 2 Singaraja are categorized as advanced level by implementing their reflective thinking.

Regarding to the implementation of life-long learning skill, the teachers always considered about their strategy in teaching and give material to students. It is also supported by Brien (2013) , the way teachers look at back and think their best strategies for the next performance is act of reflective thinking teachers. It is important to reconsider and reflect on teachers' teaching practice as it influences their students' behavior toward the material (Chee Choy et al., 2012). Besides, the teachers will get motivation in changing their teaching strategies for better self-improvement (Ball, 2009)

All of the teachers perceived that they got inspiration by their colleagues for finding the effective way of teaching. They sometimes talked to their friends about their classes and shared what happened during the learning process such as the activities, the tasks, the assessment, or the media. Sharing such information is also a part of being reflective teachers that teachers try to seek for 
others' opinion about their teaching. According to Riyanti (2020), the teachers have applied reflection-on-action, reflection that is done before or after teaching. Because of that, the teachers always make assumptions of what their colleagues and students' opinion about their teaching practice and learn from their feedback (Chee Choy et al., 2012). Therefore, T1, T3, and T4 perceived that they evaluated their teaching practice through the feedback to see their effectiveness in the online teaching. Having such information, teachers perceived that they could learn from it for improving their teaching quality. This is in line with Nguyen \& Ngo (cited in Riyanti, 2020) that teachers evaluate their teaching to make correction of what have been taught before.

Similarly, Choy and Yim (2017) noted that life-long learning skill is teachers' assessment about themselves for evaluates teaching practice and its influences students' need as continuously. It also states in Peter (cited in Choy \& Yim (2017), the teachers who use teaching strategy based on problem-based learning is said as reflective teachers. Then, the students will be self-motivated and self-directed in doing online course (Kebritchi et al., 2017). Lastly, most of the teachers thought of what they had done during their lesson then they can make correction and discover themselves to apply the material to students so they can be better teacher in the future.

The implementation of self-assess ability showed that all teachers thought they were doing quite well as teacher by reflecting on the comments from their students. According to Chee Choy et al., (2012), the teachers can be considered as good teachers in doing reflective thinking when they understand their mistakes and connect it with their past experience and improve it to the next performance. Chee Choy et al. (2012) also point out that self-assessment has connection with reflective thinking. It is because self-assessment is the way the teachers step back from past performance and improve it with better performance than before. It focuses on their teaching practice and feedback from students and colleagues (Choy \& Yim, 2017).

Even though there are still some teachers rarely get good comment for their teaching process, in relation to reflective thinking, the teachers should be asked themselves, analyzed their teaching practice, and learn their past performance by putting into the new goals (Alp \& Taşkin (cited in Yildirim, 2017). Therefore, all of the teachers considered those feedback important because it helped them to understand students better and know their strengths and weaknesses in teaching practice. By identifying their weaknesses and strengths of teaching practice, it also helps them to make improvement in the next teaching practice (Riyanti, 2020). Moreover, the teachers should think critically and creatively to make improvement of their teaching (Choy \& Yim, 2017). It is also stated by Griffths (cited in (Mathew et al., 2017) that there is opportunity to do critical reflection that will be provided by their students or other teachers to reflect teachers' performance.

Relating to teachers' self-belief, it explained that all the teachers believed that they knew about their needs as teachers such as providing lesson plan, learning media, and understands the material that will be taught before they are transferring it to students. Therefore, they always try to look for the connecting areas between how and what they teach with their life experiences. According to Choy and Yim (2017), the teachers have self-belief when they concerned about their perception and experience in teaching. Moreover, teachers perceived that 
they knew their mistakes during the teaching process could have impact on their students' life. Thus, the teachers can improve their teaching skill regarding their opportunities in reflecting their teaching practice (Pfitzner-Eden (cited in Choy \& Yim, 2017).

Moreover, teachers never felt anxious of getting feedback from their students, as it was obvious that they assessed and judged them as a person. Meanwhile, Ball (cited in (Chee Choy et al., 2012) state that the teachers should have highly metacognitive awareness of themselves and knows the best strategy to overcome the problem to reach the goals in the teaching practice. In the same vein, the teachers should understand about their teaching strategy will influence them as reflective teaching and make them as effective teachers

In relation to teaching awareness, all of the teachers perceived that they were already aware about their teaching because they always tried to think about what they taught to students. The teachers can be said as reflective teacher when they understand or master about their teaching practice and know their mistakes and how they overcome the problem and improve what the best for their teaching strategy (Riyanti, 2020). It also mentioned that the teachers ideally do reflection as their habit because it helps them to increase their teachers' professional development. Therefore, the teachers also said that they had self-quality and set of practice which they are comfortable with and they knew that all those awareness will influence their belief. Generally, the teachers will have questions what they do, make changes, and implement these changes, and they can make improvement of teaching practice while doing reflective thinking (Bölükbaş (cited in Yildirim, 2017). Therefore, all the teachers were aware that their behavior influenced their belief about themselves as a teacher toward the students' live. Chee Choy et al. (2012) also note that teaching awareness is important for teachers to analyze and understand the problem that they face during teaching practice. Moreover, Choy \& Yim (2017) also state that teachers should be more aware about their past experience and connect it with the future teaching process.

The overall response to the statements on the questionnaire showed an advance level of reflective thinking by the teachers SMP N 2 Singaraja. It can be seen by four skills such as life-long learning skill, self-belief, self-assessment, and teaching awareness that have connection with reflective thinking. Generally, it could be said that the teachers thought that was important to do reflective thinking during the online learning. Because of it, the teachers said that they needed to improve their teaching and learning strategy by integrating their past experience (Chee Choy et al., 2012). Afshar \& Farahani (2015) also note that reflective thinking can be done by the teachers if the teachers considered their teaching practices by looking their attitudes.

\section{CONCLUSION}

After analyzing the data obtained from the questionnaire, it is concluded that the reflective thinking during the online learning were in advanced level. That being said, the English teachers in SMP N 2 Singaraja were good in understanding the conceptual of the implementing reflective thinking practice. In short, there are some strengths of reflective thinking practice teachers in which they ensure that four skills e.g. life-long learning skill, self-assessment, selfbelief, and teaching awareness have connecting with reflective thinking practice. 
It also makes the teaching and learning process run smoothly by understanding the problem and make improvement to the next teaching performances. Thus, the reflective thinking practice could be important to use as teaching professional development. Further study is needed because it is only describing on how teachers perceived themselves as reflective thinking in online learning, although this study needs further study which research them in actual action of teaching and learning process.

\section{REFERENCES}

Afshar, H. S., \& Farahani, M. (2015). Reflective Thinking and Reflective Teaching among Iranian EFL Teachers: Do Gender and Teaching Experience Make a Difference? Procedia - Social and Behavioral Sciences, 192, 615-620. https://doi.org/10.1016/j.sbspro.2015.06.107

Ary, D., Jacobs, L. C., Sorensen, C., \& Razavieh, A. (2010). Introduction to Research in Education. Wadsworth, Engage Learning.

Ball, A. F. (2009). Towards a Theory of Generative Change in Culturally and Linguistically Complex Classrooms. American Educational Research Journal. 46(1), 45-72.

Balta, E. E. (2018). Reflective thinking tendencies and epistemological beliefs in terms of learning styles. International Journal of Higher Education, 7(6), 106-117. https://doi.org/10.5430/ijhe.v7n6p106

Borg, S. (2003). Teacher cognition in language teaching: A review of research on what language teachers think, know, believe and do. Language Teaching, 36, 81-109. http://dx.doi.org/10.1017/S0261444803001903

Brien, T. L. (2013). The Development of Critical Thinking Skills. Franklin Pierce University.

Burbank, M., Ramirez, L. \& Bates, A. (2012). Critically reflective thinking in urban teacher education: A comparative case study of two participants' experiences as content area teachers. The Professional Educator, 36(2), 117. https://eric.ed.gov/?id=EJ988205

Chang, B. (2019). Reflection in learning. Online Learning Journal, 23(1), 95-110. https://doi.org/10.24059/olj.v23i1.1447

Choy, C., et al. (2017). Reflective thinking among preservice teachers: $A$ Malaysian perspective Educational change View project Continuance of Virtual Learning Environment View project. https://www.researchgate.net/publication/315835575

Creswell, J. W., \& Creswell, J. W. (2007). Qualitative inquiry \& research design : choosing among five approaches. Sage Publications.

Kebritchi, Mansureh \& Lipschuetz, Angie \& Santiague, Lilia. (2017). Issues and Challenges for Teaching Successful Online Courses in Higher Education: A Literature Review. Journal of Educational Technology Systems. 46. 4-29. 10.1177/0047239516661713.

Mathew, P., Mathew, P., Prince, M., \& Peechattu, J. (n.d.). REFLECTIVE PRACTICES: A MEANS TO TEACHER DEVELOPMENT. In Asia Pacific Journal of Contemporary Education and Communication Technology. www.apiar.org.au

Nguyen, T. (2015). The Effectiveness of Online Learning: Beyond No Significant Difference and Future Horizons. MERLOT Journal of Online Learning and Teaching, 11(2), 309-319. 
Phelps, R. (2005). The Potential of Reflective Journals in Studying Complexity "In Action." Complicity: An International Journal of Complexity and Education, 2(1). https://doi.org/10.29173/cmplct8726

Ratminingsih, Ni. (2017). Method and Strategy in Teaching English. Rajawali Pers.

Riyanti, D. (2020). Students' reflections in teaching practicum: A case study of EFL pre-service teachers. Journal on English as a Foreign Language, 10(2), 268-289. https://doi.org/10.23971/jefl.v10i2.2041

Rodgers, C. (2002). Defining reflection: Another look at John Dewey and reflective thinking. Teachers College Record, 104(4), 842-866. https://www.tcrecord.org/content.asp?contentid=10890

Sandelowski, M. (2000). Whatever Happened to Qualitative Description?. Res. Nurs. Health. 23: 334-340. https://doi.org/10.1002/1098240X(200008)23:4<334::AID-NUR9>3.0.CO;2-G

Schon, D. A. (1987). Educating the Reflective Practitioner. San Francisco, CA: Jossey -Bass.

Töman, U. (2017). Investigation to Improve the Process of Pre-service Teachers' Reflective Thinking Skills through an Action Research. Universal Journal of Educational Research, 5(9), 1535-1548. https://doi.org/10.13189/ujer.2017.050911

Yildirim, T. (2017). An Examination on Geography Teachers' Reflective Thinking Tendencies. International Journal of Higher Education, 6(6), 78. https://doi.org/10.5430/ijhe.v6n6p78 